\title{
Growth, production and water consumption of coriander in hydroponic system using brackish waters
}

\author{
Mairton G. da Silva ${ }^{1}$, Itamar de S. Oliveira ${ }^{2}$, Tales M. Soares ${ }^{1}$, \\ Hans R. Gheyi ${ }^{1}$, Geocassia de O. Santana ${ }^{3}$ \& Jozelmo de S. Pinho ${ }^{4}$ \\ ${ }^{1}$ Universidade Federal do Recôncavo da Bahia/Programa de Pós-Graduação em Engenharia Agrícola/Núcleo de Engenharia de Água e Solo. Cruz das \\ Almas, BA. E-mail: mairtong@hotmail.com (Corresponding author) - ORCID: 0000-0003-2140-201X; talesmiler@gmail.com - ORCID: 0000-0001- \\ 8157-7204; hans@agriambi.com.br - ORCID: 0000-0002-1066-0315 \\ ${ }^{2}$ Fundação José Carvalho. Pojuca, BA. E-mail: itamar25souza@gmail.com - ORCID: 0000-0003-0259-3084 \\ ${ }^{3}$ Companhia Nacional de Abastecimento. Irecê, BA. E-mail: geocassia.osantana@gmail.com - ORCID: 0000-0003-0775-5628 \\ ${ }^{4}$ Associação de Pequenos Produtores de Jaboticaba. Quixabeira, BA. E-mail: jozelmopinho@gmail.com - ORCID: 0000-0001-6320-2935
}

\section{Key words:}

Coriandrum sativum L. soilless cultivation nutrient solution recirculation salinity

\begin{abstract}
A B S T R A C T
An experiment was carried out in an adapted DFT (deep film technique) hydroponic system in PVC pipes to evaluate the growth, production and water consumption of coriander $\mathrm{cV}$. 'Verdão', during June-July 2014. The experiment was carried out in a randomized block design with five replicates, in a $2 \times 4$ factorial scheme, totaling 40 plots. Two intervals of nutrient solution recirculation $(0.25$ and $2 \mathrm{~h}$ ) and four levels of water electrical conductivity (ECw 0.26, 2.47, 4.91 and $7.0 \mathrm{dS} \mathrm{m}^{-1}$ ) were evaluated. At 25 days after transplanting (DAT), the reductions in plant height and in the shoot fresh and dry matter of the bunch were 2.95, 6.08 and 3.32\% per unit increase of ECw (in $\mathrm{dS} \mathrm{m}^{-1}$ ). Despite the reductions in growth and production, saline stress did not cause any damage to the visual aspect of coriander. The accumulated water consumption for the periods of 1-20 and 1-24 DAT significantly decreased by 5.26 and $5.85 \%$ per unit increase of ECw. It was concluded that it is viable to use a nutrient solution recirculation interval of $2 \mathrm{~h}$, without production losses, and this represents a reduction of approximately $64 \%$ in electricity consumption.
\end{abstract}

\section{Palavras-chave: \\ Coriandrum sativum $\mathrm{L}$. cultivo sem solo recirculação da solução nutritiva salinidade}

\section{Crescimento, produção e consumo hídrico do coentro em hidroponia com o uso de águas salobras}

\section{R E S U M O}

Foi conduzido um experimento em sistema hidropônico DFT (técnica do fluxo profundo) adaptado em tubos de PVC para avaliar o crescimento, a produção e o consumo hídrico do coentro cv. 'Verdão', entre os meses de junho a julho de 2014. O delineamento experimental foi em blocos casualizados, em esquema fatorial $2 \times 4$, com cinco repetições, no total de 40 parcelas. Estudaram-se dois intervalos de recirculação da solução nutritiva $(0,25$ e 2 h) e quatro níveis de condutividade elétrica da água (CEa 0,26;2,47; 4,91 e 7,0 dS m m. $^{-1}$. Aos 25 dias após o transplantio (DAT), as reduções na altura de planta e nas massas de matéria fresca e seca da parte aérea foram da ordem de 2,95; 6,08 e 3,32\% por aumento unitário de $\mathrm{CEa}\left(\mathrm{em} \mathrm{dS} \mathrm{m}^{-1}\right)$. Apesar das reduções no crescimento e na produção, o estresse salino não depreciou a qualidade visual do coentro. O consumo hídrico acumulado para os períodos de 1-20 e 1-24 DAT reduziu significativamente em 5,26 e 5,85\% por aumento unitário de CEa. Concluiu-se que não houve perda na produção do coentro ao se adotar o intervalo de $2 \mathrm{~h}$ entre recirculações da solução nutritiva, obtendo-se redução no consumo de energia elétrica de aproximadamente $64 \%$. 


\section{INTRODUCTION}

In the semi-arid region of Northeast Brazil there is great availability of waters with high salt concentrations, which are not viable to be used in the irrigation of most crops. To minimize such problem, studies have proposed the hydroponic technique (soilless cultivation) to use brackish waters prohibited in the conventional system. According to Soares et al. (2007), in the hydroponic system the response of plants to salinity is better than in the soil, considering the greater availability of water to plants because in hydroponic systems matric potential of water tends to zero, which is one of the causes for the reduction in the free energy of water in the soil.

This research line has been limited to crops that are currently important in hydroponic markets, such as lettuce (Soares et al., 2010; Alves et al., 2011; Paulus et al., 2012; Soares et al., 2015). However, crops of regional interest must be investigated, especially coriander, because it has attractive prices to the producer, a place in the market of the Northeast region and tolerates high temperatures better than other vegetables (Silva et al., 2016).

In Brazil, the nutrient film technique (NFT) and deep film technique (DFT) are the hydroponic systems most used commercially. NFT is an active system which assumes pumping for nutrient solution recirculation, performing irrigations usually at $0.25 \mathrm{~h}$ intervals ( $15 \mathrm{~min}$ ) (Zanella et al., 2008). Since it depends on electricity, the expansion of hydroponics may be limited in sites where the infrastructure is inadequate to conduct electricity, which leads to inconsistency in its supply (Santos Júnior et al., 2015; Silva et al., 2016).

In this context, the DFT system adapted in PVC pipes can be promising for Brazilian rural communities where interruptions in electricity supply are frequent (Santos Júnior et al., 2015; Silva et al., 2016). In this system, roots remain submersed in the nutrient solution and, because of this advantage, it is possible to increase the intervals between recirculations, which must be investigated for each crop.

The present study aimed to evaluate the growth, production and water consumption of coriander cv. 'Verdão' grown in DFT hydroponic system adapted in PVC pipes, at two intervals of nutrient solution recirculation and use of brackish waters.

\section{Material ANd Methods}

The study was carried out in a greenhouse (East-West orientation) from June to July 2014 (winter) at the Water and Soil Engineering Center - NEAS, belonging to the Federal University of Recôncavo da Bahia - UFRB, in the municipality

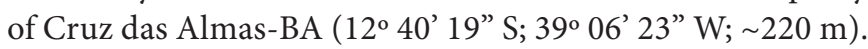

The greenhouse was $7 \mathrm{~m}$ wide and $32 \mathrm{~m}$ long, with ceiling height of $4 \mathrm{~m}$, protected on the sides by shade screen $(50 \%$ luminosity) and covered by $150-\mu \mathrm{m}$-thick polyethylene film (Figure 1A).

The experimental design was randomized blocks, in $2 \mathrm{x}$ 4 factorial scheme, with five replicates, in a total of 40 plots. The experiment evaluated two intervals of nutrient solution recirculation $(0.25$ and $2 \mathrm{~h}$ ), in a total of 33 and 12 recirculation events per day, respectively, a program performed according to Silva et al. (2016), and four levels of water electrical conductivity (ECw $0.26,2.47,4.91$ and $7.0 \mathrm{dS} \mathrm{m}^{-1}$ ), used both to prepare the nutrient solution and to replace the consumed volume. The ECw levels of 2.47, 4.91 and $7.0 \mathrm{dS} \mathrm{m}^{-1}$ were obtained by the addition of sodium chloride $(\mathrm{NaCl})$ in the water from the local supply system (ECw $0.26 \mathrm{dS} \mathrm{m}^{-1}$ ).

The experiment used the DFT hydroponic system adapted in 75-mm-diameter 6-m-long PVC pipes, proposed by Silva et al. (2016). The structure comprised 20 leveled benches ( $0.8 \mathrm{~m}$ height from soil surface), each one with two cultivation channels (Figure 1B). Each plot was represented by an independent hydroponic channel, composed of a $60-\mathrm{L}$ plastic tank containing $53 \mathrm{~L}$ of nutrient solution and a 32-watt electric pump to recirculate the solution to the cultivation channel (Figure 1C). The tanks were daily replenished using a graduated cylinder, which allowed to measure the water consumption per plot.

Seeds of coriander cv. 'Verdão' were planted in $50-\mathrm{mL}$ plastic cups containing substrate of coconut fiber. Twelve seeds were planted in each cup and then covered with vermiculite up to the top. The bottom parts of the cups were cut for the root system to pass. After germination, seedlings were manually irrigated using public-supply water (ECw $0.26 \mathrm{dS} \mathrm{m}^{-1}$ ) until the day of transplanting, which occurred 8 days after sowing (DAS), by placing 85 coriander bunches in each cultivation channel.
A.

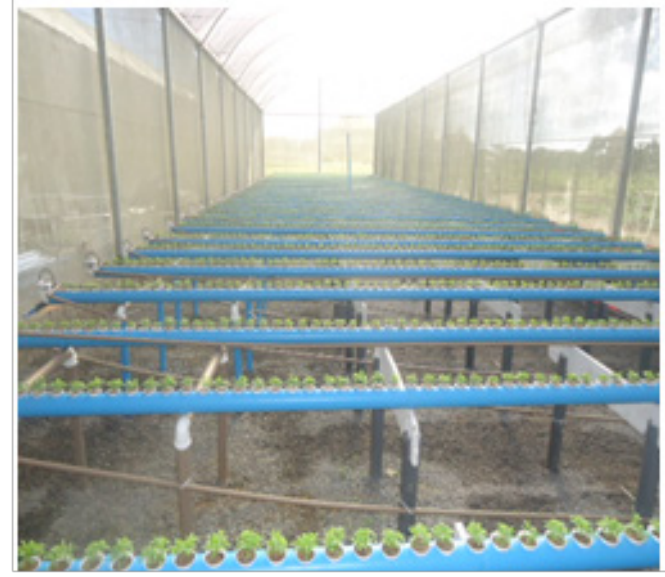

B.

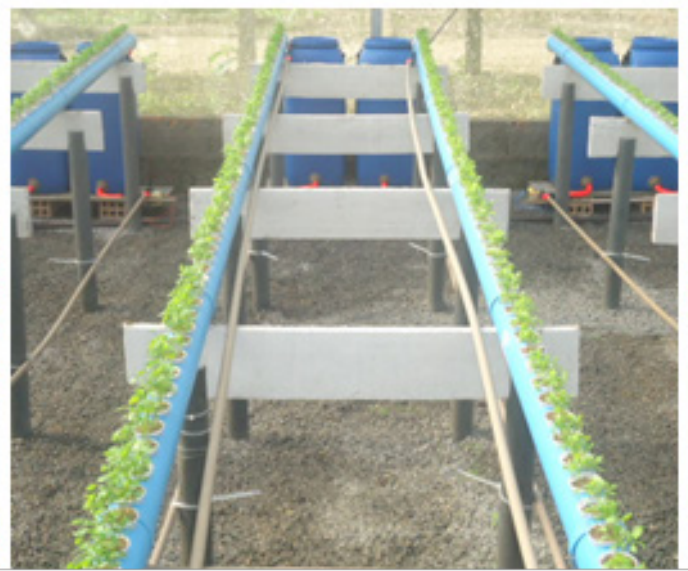

C.

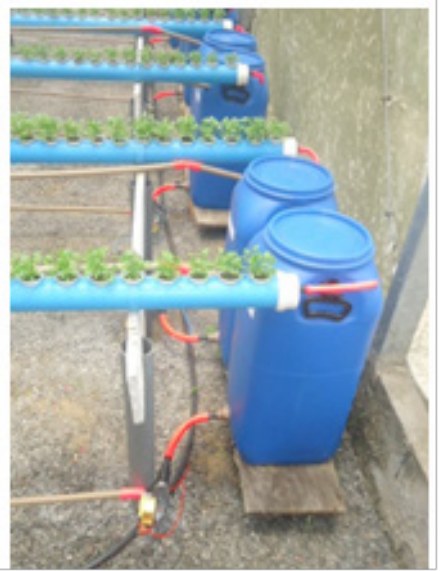

Figure 1. Overall view of the greenhouse and experimental structure (A), bench with two experimental plots (B) and tank with nutrient solution and electric pump to recirculate it to the cultivation channel (C) 
The nutrient solution used was proposed by Furlani et al. (1999) for leafy vegetables. Nutrient solutions were prepared with the water from the respective treatments (ECw 0.26, 2.47, 4.91 and $\left.7.0 \mathrm{dS} \mathrm{m}^{-1}\right)$. After adding the nutrients, the resulting electrical conductivities of the solution (ECsol) were 2.05, $4.60,6.47$ and $8.26 \mathrm{dS} \mathrm{m}^{-1}$. Along the experiment, ECsol and $\mathrm{pH}$ were monitored using a benchtop conductivity meter and a portable $\mathrm{pH}$ meter, respectively.

Harvests were carried out at 20 and 25 days after transplanting (DAT). In each plot, three coriander bunches were collected, each one containing 12 plants, to determine: plant height and shoot fresh matter. Immediately after weighing the plants, the material was placed in paper bags and dried in a forced-air oven at temperature of $65^{\circ} \mathrm{C}$ until constant weight, to quantify shoot dry matter. Plant height was measured using a tape measure from the point of cut (collar region) up to the apex.

Water consumption was calculated based on the volume consumed in the plot divided by the number of bunches in the plot, for periods of 1-20 and 1-24 DAT.
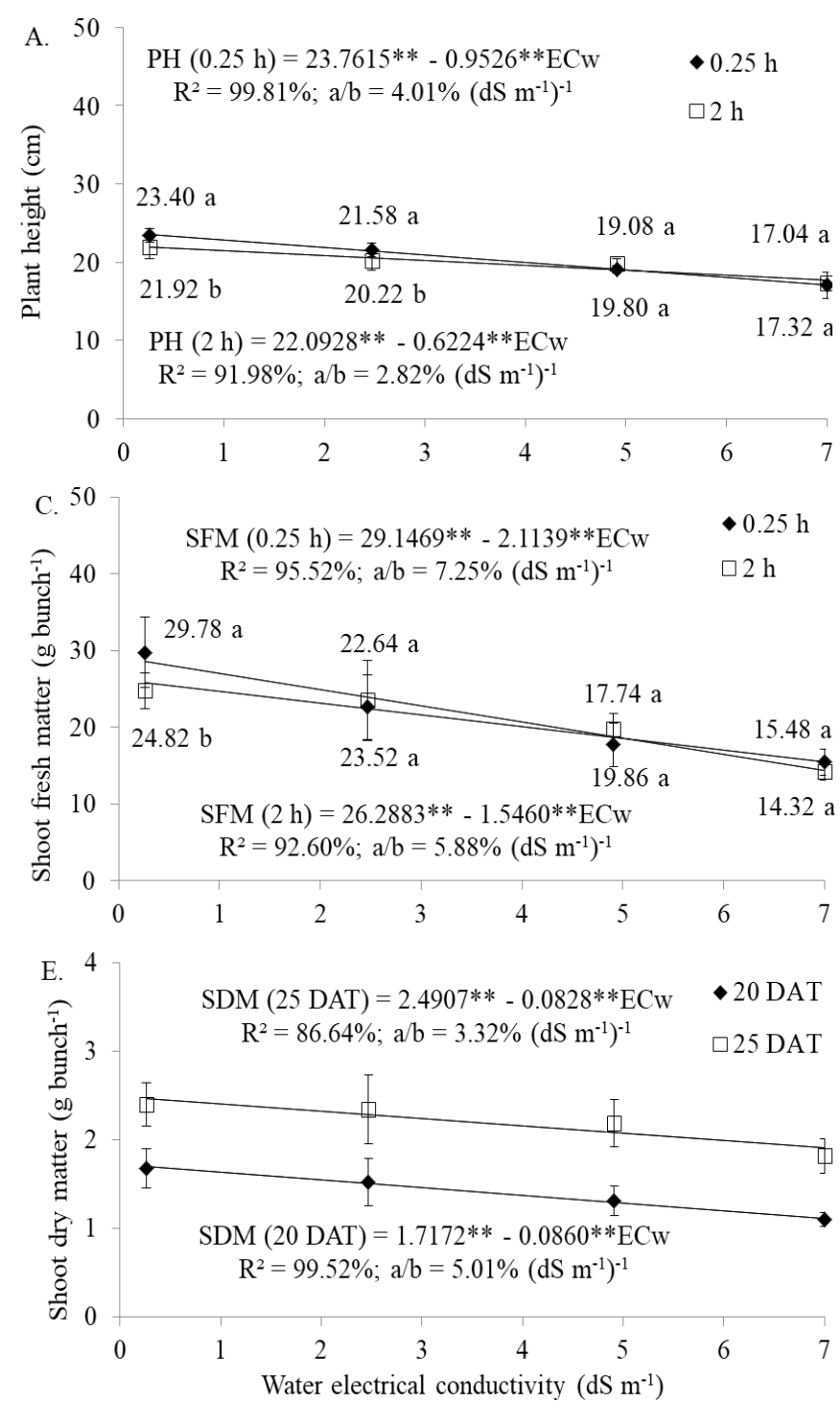

** Significant at 0.01 probability level by Student's t-test; Different letters indicate significant differences at 0.05 probability level (Tukey test) at each water salinity level; bars indicate the standard deviations of the means

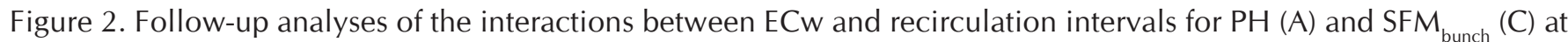
20 DAT; individual effect of ECw on $\mathrm{PH}(\mathrm{B})$ and SFM consumption for the periods of 1-20 and 1-24 DAT $(F)$
The data were subjected to analysis of variance by $\mathrm{F}$ test; means relative to the recirculation intervals were compared by Tukey test at 0.05 probability level, whereas means relative to brackish waters were evaluated by regression analysis.

\section{Results AND Discussion}

The interaction between nutrient solution recirculation intervals and water electrical conductivity levels (ECw) had significant effect $(\mathrm{p}<0.05)$ on plant height $(\mathrm{PH})$ (Figure $2 \mathrm{~A})$ and shoot fresh matter of the coriander bunch $\left(\mathrm{SFM}_{\text {bunch }}\right)$ (Figure 2C) only at 20 DAT. For the factors individually, there was significant effect $(\mathrm{p}<0.01)$ of ECw levels on $\mathrm{PH}$ (Figure 2B), SFM $_{\text {bunch }}$ (Figure 2D) and shoot dry matter of the coriander bunch $\left(\mathrm{SDM}_{\text {bunch }}\right)$ (Figure 2E), at 20 and 25 DAT, and on water consumption in the periods of 1-20 and 1-24 DAT (Figure 2F). Individually, the nutrient solution recirculation intervals did not cause significant changes $(\mathrm{p}>0.05)$ in the studied variables, in any period. This represented a reduction of approximately $64 \%$ in electricity consumption when the longest interval between
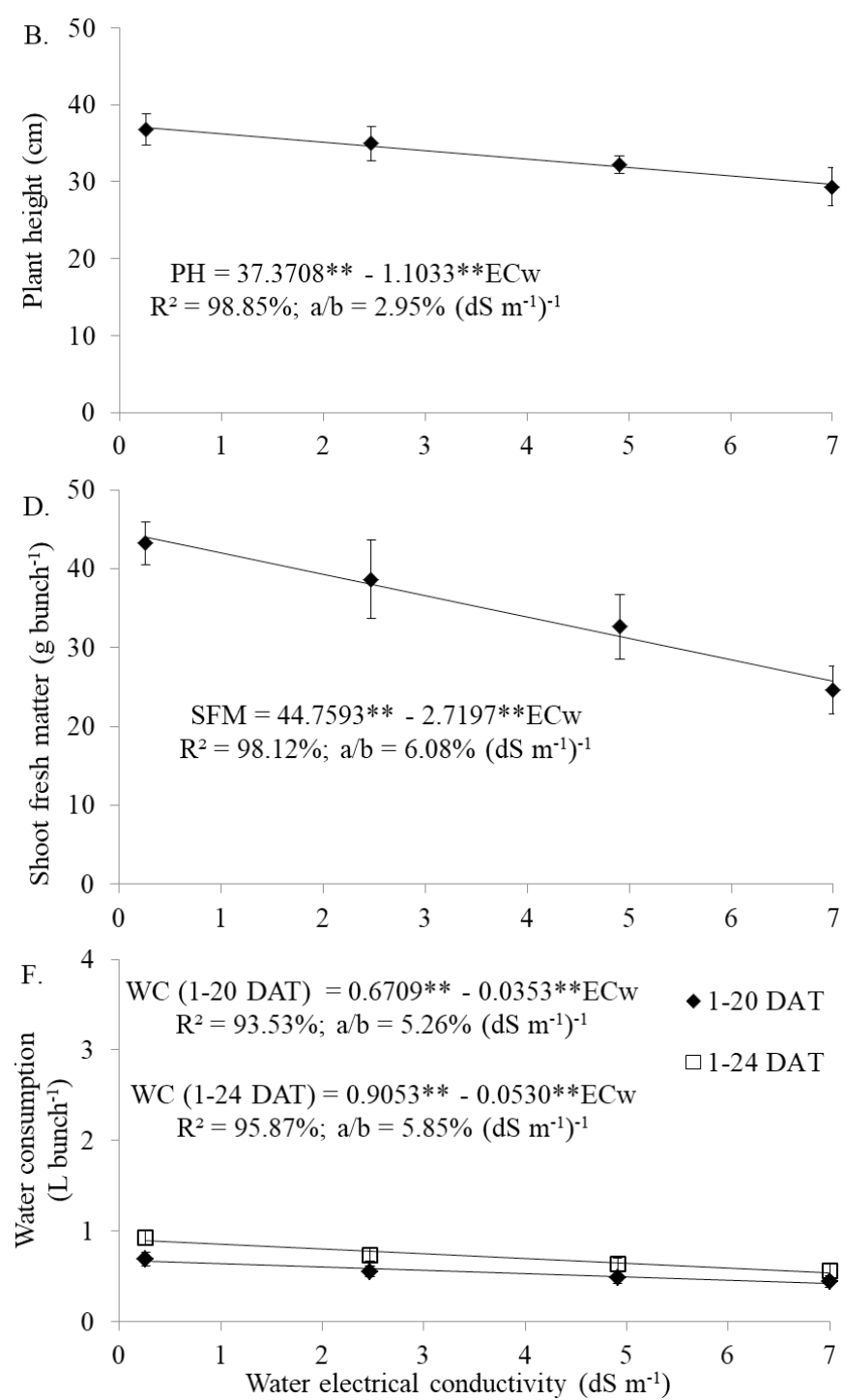

ECw and recirculation intervals for $\mathrm{PH}(\mathrm{A})$ and $\mathrm{SFM}_{\text {bunch }}(\mathrm{C})$ at
(D) at $25 \mathrm{DAT}_{\text {and }} \mathrm{SDM}_{\text {bunch }}$ (E) at 20 and $25 \mathrm{DAT}$, and water unch 
recirculations was used (every $2 \mathrm{~h}$ ), without losses in coriander production or quality. These results corroborate those of previous studies with DFT system adapted in PVC pipes. Silva et al. (2016) for coriander cv. 'Verdão' and Cova et al. (2017) for lettuce $\mathrm{cv}$. 'Tainá found that the longest recirculation intervals adopted, every 8 and $4 \mathrm{~h}$, respectively, were able to maintain the same production levels obtained with interval of $0.25 \mathrm{~h}$.

At $20 \mathrm{DAT}$, in the follow-up analysis of the interactions (ECw and recirculation intervals) the reductions per unit increase of ECW $\left(\mathrm{dS} \mathrm{m}^{-1}\right)$ were equal to 4.01 and $2.82 \%$ for $\mathrm{PH}$ (Figure 2A) and to 7.25 and $5.88 \%$ for $\mathrm{SFM}_{\text {bunch }}$ (Figure 2C) at the recirculation intervals of 0.25 and $2 \mathrm{~h}$, respectively. At 25 DAT, the reductions in PH (Figure 2B) and $\mathrm{SFM}_{\text {bunch }}$ (Figure 2D) were 2.95 and $6.08 \%$ per $\mathrm{dS} \mathrm{m} \mathrm{m}^{-1}$.

For $\mathrm{SDM}_{\text {bunch }}$ (Figure 2E), the reductions were lower in comparison to $\mathrm{SFM}_{\text {bunch }}$, about 5.01 and $3.32 \%$ per $\mathrm{dS} \mathrm{m} \mathrm{m}^{-1}$ at 20 and 25 DAT, respectively. Since the interest is not dry matter production, the production based on fresh matter was emphasized, which is the usual form of coriander marketing.

At 20 DAT, the greater reductions in $\mathrm{PH}$ (Figure 2A) and $\mathrm{SFM}_{\text {bunch }}$ (Figure 2C) for the recirculation interval of $0.25 \mathrm{~h}$ are due to the higher means observed under these cultivation conditions in comparison to the 2-h interval, between the ECw levels of 0.26 and $2.47 \mathrm{dS} \mathrm{m}^{-1}$ for $\mathrm{PH}$ and only at ECw of $0.26 \mathrm{dS} \mathrm{m}^{-1}$ for $\mathrm{SFM}_{\text {bunch }}$. In general, the maximum reduction in $\mathrm{PH}$ estimated by the linear model was $6.42 \mathrm{~cm}$ at the

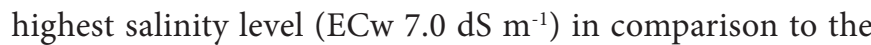
non-saline condition (ECw $0.26 \mathrm{dS} \mathrm{m}^{-1}$ ) for the recirculation interval of $0.25 \mathrm{~h}$. At $25 \mathrm{DAT}$ (Figure 2B), within this 5-day period there was greater growth in height for the interval of $2 \mathrm{~h}$ at ECw levels of 0.26 and $2.47 \mathrm{dS} \mathrm{m}^{-1}$. Under extreme conditions of salinity, the reduction was equal to $7.44 \mathrm{~cm}$, with mean $\mathrm{PH}$ of $37.08 \mathrm{~cm}$ at ECw of $0.26 \mathrm{dS} \mathrm{m}^{-1}$.

Greater reductions in $\mathrm{SFM}_{\text {bunch }}$ demonstrate that the effect of salinity was more drastic on the production based on fresh matter. These reductions in coriander leaf weight were not only due to the decrease of the growth in height, but also to the decline in stem diameter and leaf size (leaf area). Corroborating the present study, Cazuza Neto et al. (2014a), under the same climatic conditions, reported the lowest reductions in the growth variables, about 4.23 and $4.37 \%$ per $\mathrm{dS} \mathrm{m}^{-1}$ for stem diameter and plant height, whereas the reduction in SFM was $8.84 \%$ per $\mathrm{dS} \mathrm{m}^{-1}$. In that study, the coriander cv. 'Verdão' was grown in NFT hydroponic system and subjected to water salinity levels of $0.3,1.88,2.6,4.0$, $5.34,6.69$ and 7.73 (used to prepare the nutrient solution and to replace the consumed volume).

In the hydroponic cultivation, the responses of crops to salinity greatly depend on the type of strategy employed to utilize these waters. In the study of Silva et al. (2015), also conducted at the same site but using NFT system, the authors used water with salinity levels of $0.43,3.09,6.87$ and $8.53 \mathrm{dS} \mathrm{m}^{-1}$ only to replace the volume consumed by the coriander cv. 'Verdão' and observed that its growth in height was not significantly influenced in any period evaluated (7,

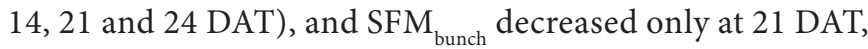
but just by $2.10 \%$ per $\mathrm{dS} \mathrm{m}^{-1}$.
Unlike the present study, Rebouças et al. (2013) evaluated the coriander cv. 'Verdão' grown for 28 days in substrate (coconut fiber) subjected to different levels of nutrient solution salinity (ECsol 2.55, 4.68, 6.85, 9.38 and $12.34 \mathrm{dS} \mathrm{m}^{-1}$ ) and found that, among the growth variables, the greatest reductions occurred in plant height and leaf area, on the order of 12.16 and $13.87 \%$ per $\mathrm{dS} \mathrm{m}^{-1}$, whereas the number of leaves decreased by $7.48 \%$ per $\mathrm{dS} \mathrm{m} \mathrm{m}^{-1}$. This demonstrates that, under saline stress conditions, the strategy of the coriander plant is to reduce leaf size and not to completely stop producing the leaves. In the study of Sá et al. (2016), coriander was cultivated for 20 days (in soil + substrate, $1: 1)$ subjected to irrigation water salinity levels of $0.6,1.2,1.8$, 2.4 and $3.0 \mathrm{dS} \mathrm{m} \mathrm{m}^{-1}$, and the reductions for cultivars 'Verdão' and 'Português Pacífico' per dS $\mathrm{m}^{-1}$ were 26.15 and $18.35 \%$ in the number of leaves, 24.47 and $18.58 \%$ in SDM and 20.22 and $19.17 \%$ in plant height, respectively, which were more drastic than those observed in stem diameter (8.02 and 8.98\%).

The divergence between the results of the different studies can be attributed to the different cultivation conditions as well as to the period of plant exposure to saline stress. According to Andriolo et al. (2008), environmental variables are the main factors affecting plant tolerance to salinity, and the reduction is more significant under conditions of high water demand by the plant. As a consequence, a more negative result can be expected in the effect of salinity on the yields of crops cultivated in the summer. Such assertion demonstrates that studies on salinity, when conducted under hydroponic conditions, despite the fact that the responses of crops are confirmedly better than in conventional systems, should be repeated under contrasting climate conditions and for different cultivars of the same species.

At salinity level of $0.26 \mathrm{dS} \mathrm{m}^{-1}$ at $20 \mathrm{DAT}$ (Figure 2C), $\mathrm{SFM}_{\text {bunch }}$ production was $29.78 \mathrm{~g} \mathrm{bunch}^{-1}$ for the $0.25-\mathrm{h}$ interval, decreasing to $24.82 \mathrm{~g} \mathrm{bunch}^{-1}$ for the 2 -h interval. In the follow-up analysis of the ECw levels for each interval, $\mathrm{SFM}_{\text {bunch }}$ production was estimated (by the linear models) as 28.60 and $25.89 \mathrm{~g} \mathrm{bunch}^{-1}$ for the intervals of 0.25 and $2 \mathrm{~h}$, respectively. Five days after the first evaluation (at 25 DAT) (Figure 2D), there was higher $\mathrm{SFM}_{\text {bunch }}$ production for the 2-h interval, which led to the absence of significant interaction, and a production of $44.05 \mathrm{~g} \mathrm{bunch}^{-1}$ was estimated at ECw of $0.26 \mathrm{dS} \mathrm{m}^{-1}$.

The $\mathrm{SFM}_{\text {bunch }}$ production obtained in the present study is consistent with those reported in other studies under hydroponic conditions. Santos Júnior et al. (2015) obtained a

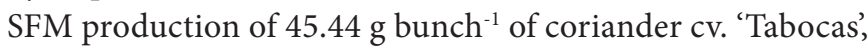
considering a sowing density of $0.5 \mathrm{~g}$ of seeds per cultivation cell at 28 DAS, and Silva et al. (2016) found production of $50.33 \mathrm{~g}$ bunch $^{-1}$ of 12 coriander plants cv. 'Verdão' at 25 DAT under ECw of $0.32 \mathrm{dS} \mathrm{m}^{-1}$.

The strategy of two harvests along the experiment allowed to identify the best period for plant harvest. Since coriander is commercialized based on fresh matter, with highest production obtained at 25 DAT, it is more advantageous to maintain plants in the hydroponic system during this period. However, it should be pointed out that plants harvested at 20 DAT had enough size to be marketed, despite the lower volume of fresh 
matter. Therefore, if the consuming market needs the product earlier, more than one bunch of plants can be put together to reach the standard volume of commercialization, as a strategy.

Cumulative water consumption decreased by 5.26 and $5.85 \%$

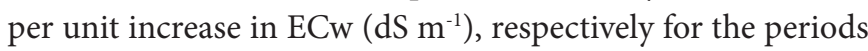
of 1-20 and 1-24 DAT (Figure 2F), and water volumes of 0.66 and $0.89 \mathrm{~L}$ were required to produce one bunch of 12 coriander plants at the lowest $\mathrm{ECw}\left(0.26 \mathrm{dS} \mathrm{m}^{-1}\right)$. In the study of Cazuza Neto et al. (2014b), in NFT hydroponic system under ECw levels of $0.30,1.88,2.6,4.0,5.34,6.69$ and $7.73 \mathrm{dS} \mathrm{m}^{-1}$, in the period of $25 \mathrm{DAT}$, a mean volume of $2.59 \mathrm{~L}$ was necessary to produce one bunch of 8 plants at ECw of $0.30 \mathrm{dS} \mathrm{m}^{-1}$. In DFT system in pipes, Silva et al. (2016) reported water consumption of $1.45 \mathrm{~L}$ to produce one bunch of 12 coriander plants at ECw of $0.32 \mathrm{dS} \mathrm{m}^{-1}$, from 2 to 24 DAT. In the work of Silva et al. (2017), using NFT system, the ECw levels of $0.43,3.09,6.87$ and $8.53 \mathrm{dS} \mathrm{m}^{-1}$ caused no statistical difference in water consumption, and a mean water volume of $2.21 \mathrm{~L}$ was used to produce one bunch of 24 plants.

Hydroponic cultivation, for requiring smaller water volume compared with the conventional planting, can be implemented in sites with low water availability, where it is not possible to use irrigation, besides the possibility of using marginal waters prohibited in the conventional planting, which is consistent with the reality of small producers from rural communities in the Brazilian semi-arid region.

With this advantage, the producer can utilize various strategies depending on the source of water available. Since the rains are concentrated in some months of the year, the knowledge on crop water requirement can be used to calculate the water volume needed to maintain the production of each month. Thus, one option would be to store rainwater to meet the production in the dry period and another option would be the direct use of brackish waters available in wells perforated in this region. If the salt concentrations in these waters are very high, they can be mixed with rainwater to reduce salinity and, consequently, the damages to plants.

\section{Conclusions}

1. Water with salinity of up to $7.0 \mathrm{dS} \mathrm{m} \mathrm{m}^{-1}$ can be used in coriander cultivation in DFT hydroponic system adapted in PVC pipes, despite the reductions in growth and production, but without deleterious effects on the visual quality of the product.

2. Cumulative water consumption of coriander was equal to $0.89 \mathrm{~L} \mathrm{bunch}^{-1}$ in the period of 1-24 DAT using water with electrical conductivity of $0.26 \mathrm{dS} \mathrm{m}^{-1}$.

3. The interval of $2 \mathrm{~h}$ between nutrient solution recirculations can be adopted without losses in coriander production, leading to reduction in electricity consumption.

\section{ACKNOWLEDGMents}

To the Bahia State Research Support Foundation (FAPESB) for granting the scholarship to the first author and for the financial support, to the Coordination for the Improvement of
Higher Education Personnel (CAPES), to the National Institute of Science and Technology in Salinity (INCTSal) and to the National Council for Scientific and Technological Development (CNPq) for the financial support.

\section{Literature Cited}

Alves, M. S.; Soares, T. M.; Silva, L. T.; Fernandes, J. P.; Oliveira, M. L. A.; Paz, V. P. S. Estratégias de uso de água salobra na produção de alface em hidroponia NFT. Revista Brasileira de Engenharia Agrícola e Ambiental, v.15, p.491-498, 2011. https:// doi.org/10.1590/S1415-43662011000500009

Andriolo, J. L.; Madalóz, J. C. C.; Godoi, R. dos S.; Janisch, D. I.; Barros, C. A. P. de. Tolerance to salinity of chicory plants grown in hydroponics. Ciência Rural, v.38, p.1142-1144, 2008. https:// doi.org/10.1590/S0103-84782008000400038

Cazuza Neto, A.; Soares, T. M.; Bione, M. A.; Freitas, F. T. O. de; Melo, D. M. de; Silva Filho, J. A. da. Qualidade do molho de coentro produzido em água salobra em sistema hidropônico NFT. In: Brazilian Symposium on Salinity, 2, e Brazilian Meeting on Irrigation Engineering, 2014, Fortaleza. Anais... Fortaleza: INOVAGRI/INCT-EI/INCTSal, 2014a. p.3678-3684. https://doi. org/10.12702/ii.inovagri.2014-a493

Cazuza Neto, A.; Soares, T. M.; Bione, M. A.; Freitas, F. T. O. de; Melo, D. M. de; Silva Filho, J. A. da. Efeito da salinidade no consumo hídrico do molho de coentro produzido em sistema hidropônico NFT. In: Brazilian Symposium on Salinity, 2, e Brazilian Meeting on Irrigation Engineering, 2014, Fortaleza. Anais... Fortaleza: INOVAGRI/INCT-EI/INCTSal, 2014b. p.3685-3693. https://doi. org/10.12702/ii.inovagri.2014-a494

Cova, A. M. W.; Freitas, F. T. O. de; Viana, P. C.; Rafael, M. R. S.; Azevedo Neto, A. D. de; Soares, T. M. Content of inorganic solutes in lettuce grown with brackish water in different hydroponic systems. Revista Brasileira de Engenharia Agrícola e Ambiental, v.21, p.150-155, 2017. https://doi.org/10.1590/1807-1929/ agriambi.v21n3p150-155

Furlani, P. R.; Silveira, L. C. P.; Bolonhezi, D.; Faquin, V. Cultivo hidropônico de plantas. Campinas: IAC, 1999. 52p. Boletim Técnico, 180

Paulus, D.; Paulus, E.; Nava, G. A.; Moura, C. A. Crescimento, consumo hídrico e composição mineral de alface cultivada em hidroponia com águas salinas. Revista Ceres, v.59, p.110-117, 2012. https://doi.org/10.1590/S0034-737X2012000100016

Rebouças, J. R. L.; Ferreira Neto, M.; Dias, N. da S.; Souza Neto, O. N. de; Diniz, A. A.; Lira, R. B. Cultivo hidropônico de coentro com uso de rejeito salino. Irriga, v.18, p.624-634, 2013. https://doi. org/10.15809/irriga.2013v18n4p624

Sá, F. V. da S.; Souto, L. S.; Paiva, E. P. de; Ferreira Neto, M.; Silva, R. A. da; Silva, M. K. do N.; Mesquita, E. F. de; Almeida, F. A. de; Alves Neto, A. Tolerance of coriander cultivars under saline stress. African Journal of Agricultural Research, v.11, p.3728-3732, 2016.

Santos Júnior, J. A.; Gheyi, H. R.; Cavalcante, A. R.; Medeiros, S. de S.; Dias, N. da S.; Santos, D. B. dos. Water use efficiency of coriander produced in a low-cost hydroponic system. Revista Brasileira de Engenharia Agrícola e Ambiental, v.19, p.1152-1158, 2015. https://doi.org/10.1590/1807-1929/agriambi.v19n12p1152-1158 
Silva, M. G. da; Soares, T. M.; Gheyi, H. R.; Oliveira, I. de S.; Freitas, F. T. O. de; Rafael, M. R. S. Consumo hídrico do coentro em hidroponia NFT com o uso de águas salobras para reposição do consumo evapotranspirado. In: Inovagri International Meeting, 4, Congresso Nacional de Irrigação e Drenagem, 26, e Simpósio Brasileiro de Salinidade, 3, 2017, Fortaleza. Anais... Fortaleza: Inovagri/ESALQUSP/ABID/UFRB/INCT-EI/INCTSal/Instituto, 2017. https://doi. org/10.7127/iv-inovagri-meeting-2017-res0740720

Silva, M. G. da; Soares, T. M.; Gheyi, H. R.; Oliveira, I. de S.; Silva Filho, J. A. da; Carmo, F. F. do. Frequency of recirculation of the nutrient solution in the hydroponic cultivation of coriander with brackish water. Revista Brasileira de Engenharia Agrícola e Ambiental, v.20, p.447-454, 2016. https://doi.org/10.1590/1807-1929/agriambi.v20n5p447-454

Silva, M. G. da; Soares, T. M.; Oliveira, I. de S.; Santos, J. C. da S.; Pinho, J. S.; Freitas, F. T. O. de. Produção de coentro em hidroponia NFT com o uso de águas salobras para reposição do consumo evapotranspirado. Revista Brasileira de Agricultura Irrigada, v.9, p.246-258, 2015. https://doi.org/10.7127/rbai.v9n400319
Soares, H. R.; Silva, E. F. de F. e; Silva, G. F. da; Pedrosa, E. M. R.; Rolim, M. M.; Santos, A. N. dos. Lettuce growth and water consumption in NFT hydroponic system using brackish water. Revista Brasileira de Engenharia Agrícola e Ambiental, v.19, p.636-642, 2015. https://doi.org/10.1590/1807-1929/agriambi. v19n7p636-642

Soares, T. M.; Duarte, S. N.; Silva, E. F. F.; Jorge, C. A. Combinação de águas doce e salobra para produção de alface hidropônica. Revista Brasileira de Engenharia Agrícola e Ambiental, v.14, p.705-714, 2010. https://doi.org/10.1590/S1415-43662010000700004

Soares, T. M.; Silva, E. F. de F. e; Duarte, S. N.; Melo, R. F.; Jorge, C. de A.; Silva, E. M. B. Produção de alface utilizando águas salinas em sistema hidropônico. Irriga, v.12, p.235-248, 2007.

Zanella, F.; Lima, A. L. da S.; Silva Júnior, F. F. da; Maciel, S. P. A. Crescimento de alface hidropônica sob diferentes intervalos de irrigação. Ciência e Agrotecnologia, v.32, p.366-370, 2008. https://doi.org/10.1590/S1413-70542008000200003 